charakteru, upodobań i światłości kobiet: „[...] Moga burzyciele zagrabiać narody, zbierać i niszczyć te księgi, w których zapisane sa plemiona ludzkiego szczęscia i klęski, ale nie zatłumia w ustach matek tych pieśni, którymi one przypominaja dzieciom, że miały ojczyznę"26.

Nakreślony przez K. z Tańskich Hoffmanowa wizerunek matki odpowiadał ówcześnie lansowanemu ideałowi kobiety. Takim ideałem miała być przykładna żona, troskliwa i rozumnie wychowująca matka, nauczycielka młodego pokolenia, świadoma swej spolecznej roli Polka. Cechować ja miały oparte na dekalogu: bezwarunkowa miłość, dobroć, wybaczenie ${ }^{27}$.

Hoffmanowa nakreśliła niezależny od podziałów społecznych wspólny tak dla drobnomieszczan, szlachty, robotnika czy chłopa obraz matki, co ważne, z wyraźnie zarysowaną cechą Matki - Polki. Na pierwszy plan wysuwa podstawowe $\mathrm{i}$ instynktowne funkcje matki, matka ma przede wszystkim kochać i wychowywać ${ }^{28}$. Niewatpliwie inspiracją dla Hoffmanowej były idee dotyczące wychowania w rodzinie formułowane w tym czasie przez polskich pedagogów, a bodźcem do stworzenia takiego wizerunku matki sytuacja polityczno-społeczna, w jakiej przyszło rodzinie polskiej wychowywać młode pokolenie Polaków.

Tworząc wizerunek matki - nauczycielki, wychowawczyni, przyjaciółki i powiernicy, stworzyła Hoffmanowa uniwersalny portret matki, odpowiadajacy duchowi XIX wieku, ale aktualny do dnia dzisiejszego.

Z kolei ideał kobiety, jaki wykształcił się na przestrzeni XIX wieku uległ diametralnej zmianie $w$ wieku XX, nie jest on już tożsamy $z$ wizerunkiem matki. Obecnie kobieta jest postrzegana nie tylko w roli żony i matki, a co ważniejsze nie tylko to określa jej wartość spoleczna.

Opis cech osobowych matki, a więc wrażliwość, skromność, bogobojność, oraz jej powinności i zadań wynikających z jej wychowawczej i kształcacej roli, jakie wyznaczyła Hoffmanowa matce, doskonale współgra $\mathrm{z}$ wizerunkiem matki naszkicowanym przez myslicieli europejskich: ,„[...] Mama to pokarm, miłość i ciepło światła. Być przez Nia kochanym to to samo co mieć dom, być żywym, zakorzenionym" ${ }^{29}$, „ona otworzyła moje serce na piękno przyrody; Ona obudziła ze snu mój umysł, rozszerzyła horyzonty a jej wrażliwość wywarła decydujący wpływ na kierunek mego życia" ${ }^{30}$.

\title{
„Przyjaciel Młodzieży” (1909-1939) jako źródło w badaniach nad dziejami wychowania katolickiego w początkach XX wieku
}

„Przyjaciel Młodzieży” był miesięcznikiem wydawanym w Poznaniu', drukowanym przez trzydzieści lat, w okresie pomiędzy 1909 a 1939 rokiem. Początkowo miał objętość czterostronicowej broszury, ale po 1920 roku ukazywał się w objętości dwudziestukilku stron. Pismo nie stało na wysokim

${ }^{26}$ Cyt. za S. Gawlik, Dziedzictwo pedagogiczne Klementyny z Taniskich Hoffmanowej, Opole 1995, 5. 28.

${ }^{27} \mathrm{M}$. Bienenstock, Pedagogika Klementyny z. Tańskich Hoffmanowej na tle wieku, "Wychowanie w Domu i w Szkole". Warszawa 1914, s. 4, s. 364.

${ }_{28} \mathrm{~J}$. Sobczak, Przejawy zainteresowania wychowaniem rodzinnym $w$ pracach niektórych polskich pisarzy i pedagogów u schylku XVIII $i$ w pierwszej polowie XIX wieku, [w:] Zeszyty Naukowe WSP, Studia Pedagogiczne 1992 , z. 18, s. $95-109$. s. 5 .

${ }^{29}$ E. Fromm, Matka, [w:] Mama najdroższa jedyna, wybór tekstów i obrazów Helen Exley, Częstochowa 1997.

30 I. Kant, Matka, tamże, s. 7.

Autorowi wiadomo, iż obok tego pisma istnialo inne o identycznym tytule, ale wydawane w Grudziądzu. 
poziomie literackim. Artykuły były pisane językiem potocznym, bardzo przystępnym. Tłumaczyć to można chęcia dotarcia do szerokiej rzeszy młodzieży, która w latach działalności miesięcznika w przeważajacej części nie byla zbyt wykształcona. Również niewiele można powiedzieć o autorach publikujacych na łamach „Przyjaciela”. Po prostu prawie wszystkie nie są sygnowane imieniem i nazwiskiem, a co najwyżej inicjałami. Sam dobór artykułów stwarzał wrażenie, iż miała to być autentyczna trybuna młodzieży. Redakcja zamieszczała sporo wypowiedzi i artykułów napisanych przez czytelników. W czasie swej działalności pismo ewoluowało nie tylko pod względem objętości, ale i kręgu środowisk, do których było adresowane. Początkowo ukazywało się z podtytułem „Pismo poświęcone katolickiej młodzieży polskiej zatrudnionej w przemyśle, kupiectwie i rolnictwie". Brak było skonkretyzowania organizacji, która pismo reprezentuje, a podkreślona została raczej orientacja środowiskowa. W lat 20-tych pojawił się podtytul „Pismo Stowarzyszeń Młodzieży Polskiej”" . Na początku roku 1930 krag adresatów, w porównaniu z wydanymi wcześniej numerami, został w podtytule znacznic bardziej sprecyzowany. Stał się „Przyjaciel Młodzicży” organem jednej z kolumn Akcji Katolickiej, a mianowicie Katolickiego Stowarzyszenia Młodzieży Męskiej (dalej w skrócie KSMM) ${ }^{3}$. Pismo ewoluowało więc od orientacji środowiskowej do ściśle organizacyjnej. Jeśli chodzi o propagowany światopogląd był on przez caly czas katolicki.

Jak już wspomniano, pismo nie stało na wysokim poziomie publicystycznym. Przeważały komunikaty, krótkie opowiadania, sprawozdania i bardzo przystẹpne artykuły problemowe. Zagadnienia wychowawcze układały się w następujące grupy: wychowanie religijne, wychowanie obywatelskie, kultura fizyczna, orientacja zawodowa.

Wychowanie obywatelskie upowszechniane było głównie za pomoca krótkich not o ważnych wydarzeniach historycznych. Najczęściej podkreślały bohaterstwo i poświęcenie opisywanych bohaterów ${ }^{4}$.

Obok tego typu opowiadań pojawialy się informacje z życia kraju i świata. Mialy one na celu głównie kształtowanie zaufania do polityki Rzeczypospolitej oraz prowadzenie szeroko rozumianej akcji scalenia ze soba ziem polskich, które były bardzo zróżnicowane w wyniku pozostawania pod rządami trzech zaborczych państwowości.

W ramach artykułów o polityce wewnętrznej i zewnętrznej państwa polskiego starano się wytłumaczyć w sposób bardzo przystępny działania organów administracji, zmagających się z problemami zadłużenia Polski, bezrobocia oraz analfabetyzmu. W numerach z lat 30 -tych zaczynały być dostrzegalne oznaki wyraźnego włączenia się w politykę propaństwową rządów sanacyjnych. Było to o tyle ciekawe, iż redakcja pisma mieściła się w stolicy Wielkopolski, a więc na terenie tradycyjnych wpływów Narodowej Demokracji, która stała w opozycji do rządów piłsudczyków.

Oczywiście, zdarzały się na łamach „Przyjaciela” wypowiedzi krytyczne na tematy polityczne, ale nie dotyczyły one państwa, Rzeczypospolitej, jako organizacji politycznej stojącej na straży Polaków, a co najwyżej poszczególnych jej agend. Krytykowano na przykład sejm za przyjęcie możliwości rozwodów, co było o tyle zrozumiale, iż stało w sprzeczności z doktryną kościoła katolickiego na temat nierozerwalności małżeństwa ${ }^{5}$.

Wytykano kolejnym ekipom rządowym brak kompleksowego rozwiazania problemów wsi ${ }^{6}$. Podkreślano, że wieś, mimo posiadania w życiu politycznym szerokiej reprezentacji $w$ postaci partii politycznych, nie mogła doczekać się rzeczowej debaty nad swoimi problemami. Z czasem w piśmie pojawiały się teksty próbujące zasiać wśród mieszkańców wsi potrzebę wyłonienia swojej nowej reprezentacji ${ }^{7}$.

${ }^{2}$ W numerach jest mowa np. zarówno o harcerstwie, jak i o organizacjach Ligi Katolickiej. Szerzej patrz np.: K. Jeżyna, Akcja Katolicka w ll Rzeczypospolitej, Lublin 1996.

3 Ibidem.

"Sowa, Sobieski wzorem dla druha, „Przyjaciel Młodzieży” 1933, nr 9, s. 133; jak również Bohaterzy, „Przyjaciel Młodzieży” 1935, nr 5, s. 104.

5. Wlimkiewicz, Ustapi, czy nie ustapi?, „Przyjaciel Młodzieży” 1935, nr 6, s. 135.

6 J. Radlo, Czego potrzebuje wies, „Przyjaciel Młodzieży” 1935, nr 1, s. 23.

${ }^{7}$ Próbę oderwania wsi od partii chlopskich można tłumaczyć zbliżeniem i protekcją z jaką z ich strony spotkal się Polski Kościół Narodowo-Katolicki - za Jerzy Kłoczkowski, Dzieje chrześcijaństwa polskiego, Warszawa 2000. s. 307. 
Krytykowano rządy za brak długofalowej polityki zwalczania bezrobocia. Według twórców pisma wprowadzenie jedynie systemu zasiłkowego prowadziło, co najwyżej, do powstania całej rzeszy podopiecznych, którzy z czasem tracili jakąkolwiek motywacje do pracy i zasilali szeregi żebraków ${ }^{8}$.

Obok krytyki niektórych działań organów państwowych piętnowano w kontekście wychowania obywatelskiego szczególnie szeroko rozpowszechniony alkoholizm w społeczeństwie polskim. Wykazywano straty zdrowotne i materialne, jakie człowiek ponosi w wyniku nadużywania alkoholu. W latach dwudziestych szczególnie numer drugi był poświęcony zagadnieniom alkoholizmu - w tym miesiącu Kościół Katolicki ogłaszał tydzień trzeźwości.Tygodnik w propagandzie antyalkoholowej używał głównie dwóch argumentów: moralno-teologicznego - pijaństwo jest sprzeczne z nakazami wiary katolickiej oraz ekonomicznego - powoduje popadanie w nędzę. Przeciwdziałając pladze pijaństwa mịesięcznik próbował animować ruch trzeźwościowy. Propagowano zakładanie kólek abstynenckich, które według pisma rozwijały się, ale fakt niepodawania konkretnych liczb był raczej wymowny i mówił sam za siebie?.

W ramach wychowania obywatelskiego próbowano obudzić ducha przedsiębiorczości wśród czytelników. Pokazywano nowe sposoby pozyskiwania kapitału, głównie na wsi, poprzez upowszechnianie nowych rodzajów hodowli ${ }^{10}$.

Jaki był zakres rzeczywistego oddziaływania tej propagandy? Trudno na podstawie samej analizy zawartości pisma rzeczowo odpowiedzieć na to pytanie. Pewnym wskaźnikiem może być mapa zamieszczona w numerze $10 \mathrm{z} 1929$ roku, na której oznaczono miejscowości, w których pod wpływem miesięcznika wprowadzono do końca 1928 konkurs w uprawie kukurydzy ${ }^{11}$. Było ich ogółem 300, przy czym wyraźnie dominował rejon poznański, łódzki, śląski oraz krakowski z Podhalem. W zasadzie wolne od znaków było województwo poleskie, co można tłumaczyć jego prawoslawnym charakterem ${ }^{12}$.

Wskazywano na mądre ekonomicznie zachowania nacji niemieckiej i żydowskiej, które wspierają członków swoich społeczności w przedsięwzięciach natury ekonomicznej. Według redakcji, właśnie tego ducha wspólnotowego bardzo społeczeństwu polskiemu brakowało ${ }^{13}$.

Dlatego zachęcano do modnego ówcześnie zrzeszania się w spółdzielnie. Według sprawozdania za rok 1933 członkowie KSMM i KSMŻ (Katolickie Stowarzyszenje Młodzieży Żeńskiej) prowadzili 60 przedsiębiorstw ${ }^{14}$. Ruch spółdzielczy i jego główny atut, a mianowicie jednoczący charakter, można było zdaniem „Przyjaciela” wykorzystać w celach zarobkowych i nie tylko. Zachęcano do organizowania co pewien czas prac na rzecz spoleczności lokalnych, np. naprawienie drogi, zalesienie nieużytków, zbudowanie ogrodzeń ${ }^{15}$.

Generalnie rzecz ujmując w wychowaniu obywatelskim propagowanym przez „Przyjaciela Młodzieży" wyróżnić można dwie warstwy:

${ }^{8}$ JT, Dlaczego dziad zawsze dziadem?, „Przyjaciel Młodzieży” 1935, nr 5, s. 107.

${ }^{9}$ Rozwój kótek abstynenckich, „Przyjaciel Młodzieży” 1929, nr 7, s. $154-155$.

10 Reklamowano hodowlę ryb - uwrażliwiano na umiejętność dostrzegania okazji do zarobkowania, tam gdzie się ona nadarza. Ponadto propagowano hodowlę królika. Dużym uznaniem redakcji cieszyła sį̨ uprawa kukurydzy, która wymagała gleb niezbyt urodzajnych. Podawano szczegółowe sposoby jej uprawiania oraz zagospodarowywania - np. przy karmieniu ryb. Organizowano konkursy i współzawodnictwo pomiędzy poszczególnymi oddziałami KSMM w zakresie hodowli kukurydzy. Informowano o metodach zakładania sadów morwowych i o dochodach, jakie można z nich uzyskiwać. Zachęcano do sadzenia drzew, których pyłek podnosi jakość miodu. Informowano, jak prawie profesjonalnie zająć się hodowlą pszczól. Patrz np.: Pogadanki..., „Przyjaciel Młodzieży” 1929, nr 1, s. 14; M. Krukowski, O przechowywaniu kukurydzy, „Przyjaciel Młodzieży” 1929, nr 2,s. 38-39; Karol Pływacz i Wladysław Brudny, Kukurydza na wystawie, „Przyjaciel Młodzieży", rok 1929, nr 1, s. 17; Druhowie zakladajmy sady morwowe, „Przyjaciel Młodzieży” 1935, nr 3, s. 56-57; Druhowie KSM sa postępowi, 1935, nr 3 s. 54; M.H: Peerowe „pogadajmy”, nr 4, s. 75; Wspomnienia z lustracji, „Przyjaciel Młodzieży” 1935, nr 5, s. 105; Tadeusz Woźniak, Na front ... matych wyczynów, „Przyjaciel Młodzieży” 1935, nr 6, s. 127.

"Tamże, s. 234.

12 Patrz: roczniki statystyczne z XX-lecia miedzywojennego.

13 S. Bardasz, Jak wybrać zawód?, „Przyjaciel Młodzieży” 1935, nr 6, s. 139.

14 W. Socha, Druhowie KSM I spótdzielczoś́, „Przyjaciel Młodzieży” 1935, nr 4, s. 79.

Is W. Oleksy, Od myszy do cesarza wszyscy zyja z gospodarza, „Przyjaciel Młodzieży” 1935, nr 7, s. 182. 
- pozytywną - w jej ramach wspierano państwo i propagowano zachowania majace na celu podniesienie jego poziomu zamożności,

- negatywna - gdzie wytykano pewne wady ogólnopolskie, jak: alkoholizm i brak przedsiębiorczości oraz błędną okresowo politykę szeroko rozumianej administracji.

Ogólną linia w wychowaniu obywatelskim było budzenie patriotyzmu. Powstawaniu szowinizmu narodowego miały przeciwdziałać wyżej wymienione wady narodowe i wskazywanie na potrzebę ich przezwyciężenia oraz podkreślanie zalet obcych narodowości.

Poradnictwo zawodowe zaistniało na szpaltach „Przyjaciela” od czasów I wojny światowej. Jego przykładem może być cykl artykulów pod wspólnym tytulem Pogadanki zawodowe publikowany w roku 1915 i $1916^{16}$, z lat dwudziestych artykuł pt. Przygotowanie do zycia spotecznego ${ }^{17}$, czy też seria z trzeciej dekady XX-wieku pod tytułem Jak wybrać zawód? ${ }^{18}$. Pod względem merytorycznym widać znaczna ewolucję prezentowanych treści. Poczatkowo stały one na pograniczu teologii pastoralnej, poradnictwa zawodowego i zdroworozsądkowej porady. Podkreślano potrzebę uwzględnienia zainteresowań, zwalczanie lenistwa, kładzenie nacisku na staranność, a wszystko przez wzgląd na służbę Bogu i bliźniemu. $\mathrm{Z}$ czasem pojawiały się artykuły o terminologii bardziej fachowej. Zaczynały być upowszechniane pierwsze próby profesjonalnej diagnozy pedagogiczno-psychologicznej i informowano, gdzie można ja wykonać. Nie brakowało ogłoszeń o możliwości podjęcia kształcenia zawodowego ${ }^{19}$. Widać wyraźnie przejście od tonu gawędziarskiego w narrację bardziej pogłębiona, uwzględniająca osiagnięcia ówczesnej nauki ${ }^{20}$. Pojawia się nawet próba projektowania rozwoju zapotrzebowania na poszczególne zawody na rynku pracy. Na przykładzie Wojewódzkiego Instytutu Rzemieślniczo-Przemysłowego w Poznaniu przybliżono diagnozowanie zawodowe. W Instytucie tym, Poradnia Zawodowa dokonywała badań młodzieży pod względem medycznym i psychologicznym. Przy czym odbywala się ona $\mathrm{z}$ wykorzystaniem wszystkich ówczesnych zdobyczy techniki $\mathrm{i}$ nauk psychologicznych. Diagnozowano: uwagę, spostrzegawczość, inteligencję, zdolności słowne, manualne, czy konstrukcyjne. Tłumaczono, dlaczego pewne wrodzone predyspozycje są w niektórych profesjach niezbędne. Co istotne, w przykładach zawsze odwoływano się do sytuacji, w których niezgodnie ze zdolnościami obrany fach mógł ściagnąć nieszczęście na drugiego człowieka. Dostępne były darmowe badania lekarskie. Po zakończeniu pobytu w Poradni Instytutu młody człowiek dostawał listę zawodów, do których posiadał predyspozycje. Ponadto był orientowany, jakie zawody ciesza się największym popytem na rynku pracy i jak będzie się kształtowalo jego zapotrzebowanie po skończeniu nauki w wybranym zawodzie ${ }^{2 !}$. Łamy „Przyjaciela” przestrzegaly przed tzw. owczym pędem przy obieraniu profesji - może to spowodować zupełnie niepotrzebne frustracje. Na przykład, według redakcji miesięcznika najbardziej popularny wśród młodzieży był zawód wojskowego, a przecież wojsko nie mogło wchłonąc nieograniczonej liczby absolwentów szkół średnich. Poradnictwo zawodowe nie było w „Przyjacielu” ograniczone tylko do młodzieży sprawnej umysłowo i fizycznie. Omawiano również specjalistyczne możliwości orientacji zawodowej młodzieży upośledzonej, jak i wybitnie zdolnej.

\footnotetext{
If Tamże.

${ }^{17}$ Pod tym samym tytułem, „Przyjaciel Młodzieży” 1928, nr 4, s. $71-73$.

${ }^{18}$ S. Bardasz, op. cit., 1935, nr 4, 5, 6 i 8.
}

19 Patrz np. ogłoszenie o naborze do Centrum Towarzystwa Rolniczego w Pszczynie na 2,5 roczny kurs doskonalenia rolniczego, „Przyjaciel Młodzieży” 1927, nr 10, s. 199; czy S. Syrynsz Zaleski, Kursy rolnicze przyjda wam same na zebrania!, „Przyjaciel Młodzieży” 1929, nr 10, s. 224.

${ }^{20}$ Patrz również np.: "Sprawozdanie Towarzystwa Polsko - Katolickich terminatorów w Berlinie za rok 1914, „Przyjaciel Młodzieży” 1915, nr 4, s. 14-15; reklama książki „Na co zważać należy przy wyborze zawodu dla mlodzieży?”, „Przyjaciel Młodzieży”, rok 1915, nr 4, s. 16; Wiadomości zwiazkowe, „Przyjaciel Młodzieży”, strona tytulowa numeru 10-tego z 1916; S. Syrynsz Zaleski, Przypomnienia gospodarskie, „Przyjaciel Młodzieży” 1927, nr 6, s. 115; Przygotowanie do zycia spolecznego, „Przyjaciel Młodzieży” 1928, nr 4, s. 71-73; Kim więc beqde, „Przyjaciel Młodzieży" 1933, nr 5, s. 116.

${ }^{21}$ Autor jest nauczycielem w szkole zasadniczej i nie spotkał się obecnie $z$ jakimkolwiek prognostycznym orientowaniem zawodowym uczniów. Po prostu uczeń po szkole podstawowej przychodzi z orzeczeniem, iż może wykonywać zawód np. krawca i nikt się nie martwi, czy będzie zapotrzebowanie na tę branżę, czy nie. 
W „Przyjacielu” udostępniano także przepisy i ustawy pracownicze, tak aby młody człowiek nie był wyzyskiwany oraz oszukiwany przez pracodawcę ${ }^{22}$.

Generalnie poradnictwo zawodowe w każdym czasie istnienia miesięcznika miało trzy elementy wspólne: uwzględnienie dochodów z danej działalności, kierowanie się zainteresowaniem i sytuacją na rynku pracy.

Wychowanie fizyczne w praktyce sprowadzalo się do propagowania głównie gier zespołowych. Prezentowano zasady gry oraz wprowadzono cykle rozgrywek. Przy tej okazji próbowano propagować rodzima tradycje narodowa $w$ zakresie kultury fizycznej ${ }^{23}$.

Wskazywano na pewną strukturę dyscyplin sportowych $\mathrm{i}$ podkreślano, że wiele $\mathrm{z}$ nich można uprawiać wszędzie i doslownie przez cały rok. Kładziono szczególny nacisk na gimnastykę, bez której nie może obejść się żaden inny sport. Gimnastyka jest bowiem bazą dla innych dyscyplin $^{24}$

Analiza wyników sportowych publikowanych na łamach pisma, a uzyskiwanych przez czytelników na imprezach sportowych, które odbywały się pod auspicjami „Przyjaciela”, zmusza do wyciagnięcia wniosku, iż brakło w wynikach uzyskiwanych przez młodzież miejska i wiejska znaczącego zróżnicowania ${ }^{25}$. Oczywiście na tej podstawie trudno jest przesądzić o skuteczności oddziaływania miesięcznika $\mathrm{w}$ zakresie wychowania fizycznego na mlodziė̇, jednak można $\mathrm{z}$ cała pewnościa stwierdzić, iż było ono lepsze niż w zakresie działalności antyalkoholowej.

Wychowanie religijne było w piśmie o orientacji katolickiej wplecione konstytutywnie. W jego ramach upowszechniano wykład doktryny.

W zakresie teologii moralnej kładziono nacisk na poszanowanie bliźniego. Ciekawym przykładem w tej kwestii było podjęcie próby przezwyciężenia uprzywilejowanej pozycji mężczyzny i propagowania równouprawnienia płci ${ }^{26}$. Próbowano podjąć zagadnienie przełamania egoizmu i związania osoby ze społeczeństwem zarówno w sensie horyzontalnym, jak i wertykalnym. Szczególnie dużo miejsca poświęcano kwestii małżeństwa i jego nierozerwalności.

Krótkie artykuły o tematyce liturgicznej wyraźnie ukierunkowane były na przezwyciężenie płytkiej obrzędowości religijnej i przesunięcie jej do warstwy osobowościowej.

Informacje o tym, co się dzieje w polskim, jak i światowym Kościele Katolickim miały kształtować szersze spojrzenie na tematy wiary ${ }^{27}$.

Należy stwierdzić, że w zakresie treści i formy odnoszacej się do tematyki religijnej brak jest w przeciagu istnienia pisma jakichś znaczących fluktuacji.

Kończąc ten syntetyczny przegląd tematyki wychowawczej prezentowanego periodyku należy jeszcze raz podkreślić niezbyt wyskoki jego poziom, dostosowany do odbiorcy. Pewnym wskazaniem, dlaczego „Przyjaciel” był miejscami trywialny, może być uwaga dołączona do informacji o rekrutacji na trwający 2,5 roku kurs doskonalenia rolniczego, w której wśród jedynych wymienionych kryteriów zakwalifikowania wymienia się „umiejętność czytania i pisania i 4 działań arytmetycznych" ${ }^{28}$. Jako usprawiedliwienie dla redakcji można podać, iż obok tego pisma o orientacji katolickiej istniało wiele innych, tak więc czytelnik o bardziej wyrobionym guście literackim nie był skazany tylko i wyłącznie na omawiany miesięcznik.

\footnotetext{
${ }^{22}$ Patrz przypis nr 14.

${ }^{23}$ Patrz np. „Przyjaciel Młodzieży”, cykl artykułów Gry i zabawy staropolskie z 1916 roku. C. Gieysztor, Drogi rozwoju sportu na wsi, „Przyjaciel Młodzieży” 1935, nr 4, s. 81.

${ }^{25}$ Kronika sportowa 1929, nr 2, s. 45; Nasze rekordy 1929, nt 4, s. 89.

${ }_{26}$ F. Żurkowska, Szanuj kobiety, „Przyjaciel Młodzieży” 1929, nr 9, s. 198 199.

${ }^{27}$ Patrz: numery „Przyjaciela Młodzieży” z lat $1909-1939$

28 Patrz przypis $\mathrm{nr} 19$.
}

${ }^{24}$ W. Janiszewski, Sporty zimowe, „Przyjaciel Młodzieży” 1929, nr1, s. 18-19; Kajakiem na wycieczke, „Przyjaciel Młodzieży” 1933, nr 10, s. 188; Kronika $w-f$, „Przyjaciel Młodzieży” 1933, nr 4, s. 80 i nr 5, s. 91; 